\title{
Penerapan Perangkap Lipat (Traps) untuk Penangkapan Kepiting Bakau (Scylla sp.) di Kabupaten Aceh Barat Provinsi Aceh
}

\section{Applying Traps for Mud Crab (Scylla sp.) Fishing in West Aceh District Aceh Province}

\author{
Hafinuddin ${ }^{1 *}$, Uswatun Hasanah ${ }^{1}$ \\ 1 Program Studi Perikanan, Fakultas Perikanan dan IImu Kelautan, Universitas Teuku Umar, Meulaboh, \\ Indonesia \\ *Korepondensi: hafinuddin@utu.ac.id
}

\begin{abstract}
ABSTRAK
Prospek usaha penangkapan kepiting bakau menjadi pilihan yang sangat baik karena Permintaan kepiting bakau semakin meningkat dan harga pasar yang relatif bagus. Ketersediaan kepiting bakau untuk pasar lokal terutama di Kabupaten Aceh Barat dipengaruhi oleh hasil tangkapan yang sedikit, penangkapan yang tidak efesien, dimana masyarakat masih menggunakan alat tangkap serok dan adanya faktor internal serta faktor eksternal. Oleh karena itu, melihat potensi usaha penangkapan kepiting bakau maka penerapan perangkap lipat untuk penangkapan kepiting bakau yang ramah lingkungan untuk nelayan di Kabupaten Aceh Barat sangat tepat untuk dilakukan. Penerapan perangkap lipat dilakukan di Desa Kuala Bubon Kecamatan Samatiga Kabupaten Aceh Barat Provinsi Aceh. Penerapan alat penangkapan ikan (API) perangkap lipat ini adalah kepada nelayan perintis. Metode pelaksanaan kegiatan pengabdian kepada masyarakat meliputi 1) pendampingan dan sosialiasi alat tangkap perangkap lipat dan 2) pelatihan pembuatan perangkap lipat. Hasil kegiatan menunjukkan bahwa 1) hasil tangkapan kepiting bakau lebih banyak dengan menggunakan perangkap lipat dibandingkan dengan menggunakan alat tangkap serok; 2) peningkatan keterampilan bagi masyarakat nelayan dalam pembuatan bubu lipat dan 3) peningkatan pemahaman bagi masyarakat nelayan dalam penggunaan alat tangkap ramah lingkungan untuk penangkapan kepiting bakau. Penerapan perangkap lipat untuk nelayan kepiting bakau adalah sangat potensial untuk dikembangkan.
\end{abstract}

Kata Kunci: perangkap lipat, kepiting bakau, pengabdian kepada masyarakat, IbM

\begin{abstract}
Prospect of fishing business of mud crab has became the right choice because demand of mud crab is increasing and market price is relatively good. The availability mud crab for local market in West Aceh District is affected by minimum catch, unefficient fishing, where fishermen is still using traditional fishing gear i.e. scoop net as well as having internal factor and external factor. Because of that, the potential business for mud crab fishing with eco-friendly fishing gear i.e. traps is very good to applied. Applying traps was carried out at Kuala Bubon Village Samatiga Sub district Aceh Barat District Aceh Province. Applying traps is for pilot project for fisherman. The Methods include 1) mentoring and sosialization traps; 2) training for making traps and 3) operating traps. Result of the activity show 1) fish catching using traps is better than using scoop net; 2) increased skilll for fishermen about making traps and 3) increased understanding for fisherman about using eco-friendly fishing gear to catching mud crab. Applying traps for fisherman community is very potential to developed for mud crab fishing business.
\end{abstract}

Key word: traps, mud crab, community service program, IbM

\section{PENDAHULUAN Latar Belakang}

Permintaan kepiting bakau saat ini semakin baik dan diikuti dengan kisaran harga kepiting bakau yang relatif bagus yaitu berkisar antara Rp 50.000 - 60.000 per kg sehingga 
prospek usaha penangkapan kepiting bakau menjadi pilihan yang sangat baik. Namun, ketersediaan kepiting bakau untuk pasar lokal dipengaruhi oleh hasil tangkapan yang terbatas, penangkapan yang tidak efesien, faktor internal dan eksternal. Faktor internal misalnya anggota keluarga yang sakit, adanya kegiatan desa ataupun keluarga, serta faktor eksternal misalnya hujan dan banjir.

Harga lokal kepiting bakau yang relatif bagus namun tidak diikuti oleh jumlah hasil tangkapan yang mencukupi, serta masih sedikitnya minat masyarakat yang melirik dalam usaha penangkapan kepiting bakau, menjadikan usaha penangkapan kepiting bakau ini sebagai peluang usaha yang sangat potensial, ketika aktivitas usaha penangkapan ini mampu dilakukan dengan serius, intens dan didukung oleh penerapan teknologi penangkapan tepat guna dan ramah lingkungan.

Strategi pengembangan perikanan (fishery development) salah satunya adalah dengan pengadaan atau adaptasi teknologi yang cocok (Charles, 2000). Kondisi mitra yang masih menjadikan kegiatan penangkapan kepiting bakau sebagai pekerjaan sampingan, serta prospek pasar kepiting bakau yang begitu menjanjikan sehingga pengadobsian teknologi tepat guna dan ramah lingkungan adalah sebuah keadaan yang tidak bisa ditunda lagi.

Mitra kelompok nelayan yang dipilih adalah kelompok nelayan perintis. Kelompok nelayan perintis adalah kelompok nelayan yang berada di Desa Kuala Bubon Kecamatan Samatiga. Mitra kelompok nelayan yang dipilih merupakan nelayan/individu yang selama ini melakukan penangkapan kepiting bakau dengan menggunakan serok. Aktivitas penangkapan dilakukan di malam hari dengan menyusuri sungai yang merupakan vegetasi dari mangrove dan nipah serta menggunakan senter sebagai alat bantu.

\section{Masalah}

Penggunaan alat tangkap serok untuk penangkapan kepiting bakau yang dilakukan oleh mitra kelompok nelayan penangkapan kepiting bakau, menyebabkan jumlah hasil tangkapan kepiting bakau relatif kecil dan tidak efesien. Bahkan usaha penangkapan kepiting bakau ini telah banyak ditinggalkan oleh nelayan karena hasil tangkapan yang tidak memuaskan. Selain permasalahan alat penangkapan, terdapat pula permasalahan permodalan dan manajemen usaha.

Beberapa permasalahan mitra/nelayan kepiting bakau yang dari segi alat penangkapan yaitu serok sebagai alat tangkap antara lain: (1) alat tangkap serok mengakibatkan jumlah hasil tangkapan rendah, (2) kurangnya informasi alat tangkap tepat guna dan ekonomis serta ramah lingkungan untuk penangkapan kepiting bakau, (3) masih sangat bergantungnya mitra/nelayan pada alat tangkap yang dipasarkan, dimana harganya relatif mahal walaupun jumlah hasil tangkapan lebih baik.

\section{METODELOGI}

Metode yang telah digunakan dalam pengabdian kepada masyarakat nelayan kepiting bakau adalah sebagai berikut:

1. Pendampingan dan sosialisasi mengenai alat tangkap perangkap (traps) lipat kepada anggota kelompok nelayan mitra. Kegiatan akan dilakukan dalam bentuk diskusi interaktif langsung kepada anggota kelompok nelayan mitra dengan tujuan membuka wawasan mengenai alat tangkap perangkap (traps) lipat;

2. Pelatihan pembuatan perangkap (traps) lipat meliputi:

a. Penyiapan alat dan bahan pembuatan perangkap (traps) lipat;

b. Pembuatan perangkap (traps) lipat; 
c. Penentuan daerah penangkapan yang tepat dan

d. Pengoperasian alat tangkap perangkap (traps) lipat.

3. Analisis kelayakan usaha penangkapan kepiting bakau.

Untuk pemberdayaan kelompok nelayan mitra, seluruh kegiatan penerapan alat tangkap melibatkan langsung anggota kelompok dalam pelaksanaan program seperti penyiapan alat dan bahan yang digunakan, teknik pembuatan alat tangkap, proses penentuan daerah tangkapan (fishing ground) dan teknik pengoperasian alat tangkap.

\section{HASIL DAN PEMBAHASAN}

\section{Keadaan Umum Daerah Pengabdian kepada Masyarakat}

Kabupaten Aceh Barat memiliki luas $2.927,95 \mathrm{Km}^{2}$ yang terdiri dari 12 kecamatan, 33 mukim dan 322 gampong. Wilayah Kabupaten Aceh Barat secara Geografis terletak pada $04^{\circ} 06^{\prime}-04^{\circ} 47^{\prime}$ LU dan 95 52'- 96 $36^{\circ}$ (BPS Kabupaten Aceh Barat, 2016).

Perairan umum di Kabupaten Aceh Barat terdiri dari waduk, sungai dan rawa. Luas area waduk adalah 162,0 ha, sungai dengan luas $1.749,0$ ha dan rawa dengan luas 4.554,0 ha. Adapun total luas perairan umum di Kabupaten Aceh Barat adalah 6.465,0 ha. Kabupaten Aceh Barat memiliki perairan umum terluas kedua setelah Kabupaten Aceh Timur ( 21.653,0 ha) (DKP Provinsi Aceh 2014).

Lokasi pengabdian kepada masyarakat adalah di Desa Kuala Bubon Kecamatan Samatiga Kabupaten Aceh Barat. Luas wilayah Kecamatan Samatiga adalah 140,69 $\mathrm{Km}^{2}$ atau $4,81 \%$ dari luas kabupaten. Wilayah Kecamatan Samatiga memiliki batas administrasi Kecamatan Bubon di sebelah utara, dengan Samudera Indonesia disebelah selatan, dengan Kecamatan Arongan Lambalek dan Kecamatan Johan Pahlawan di sebelah barat dan timur (BPS Kabupaten Aceh Barat, 2016). Peta lokasi pengabdian dapat dilihat pada Gambar 1.

\section{Sosialisasi Penangkapan Ikan Ramah Lingkungan}

Kegiatan sosialisai yang telah dilakukan kepada nelayan di Desa Kuala Bubon Kabupaten Aceh Barat adalah dalam bentuk diskusi interaktif langsung kepada anggota kelompok nelayan mitra. Kegiatan ini bertujuan membuka wawasan dan menambah pengetahuan mengenai pentingnya penangkapan ikan yang berkelanjutan (sustainable of fisheries). Pada pertemuan ini juga telah disampaikan tentang dampak positif dan menguntungkan penangkapan kepiting bakau menggunakan perangkap (traps) lipat. Kegiatan dilakukan dalam 2 kali pertemuan.

\section{Pelatihan Pembuatan Perangkap Lipat}

Kegiatan ini dilakukan sebanyak 7 kali pertemuan. Kegiatan ini merupakan kegiatan transfer pengetahuan teknologi yang mencakup dalam tiga kegiatan yaitu pembuatan perangkap lipat dan pengoperasian perangkap lipat.

\section{Pembuatan perangkap lipat}

Pembuatan perangkap lipat dimulai dengan persiapan bahan dan alat. Adapun alat dan bahan yang digunakan adalah sebagai berikut:

- Alat

Alat yang digunakan dalam kegiatan pembuatan perangkap lipat terdiri atas pemotong kawat, pembengkok besi, tang, gergaji besi, penggaris, coban, sarung tangan, mal perangkap lipat, gunting dan cutteripisau. 
- Bahan

Bahan yang digunakan dalam kegiatan pembuatan perangkap lipat dapat dilihat pada Tabel 1.

Perangkap lipat yang dibuat atau ditransfer ke mitra adalah perangkap lipat dengan ukuran panjang $(P)=50 \mathrm{~cm}$, lebar $(L)=30 \mathrm{~cm}$, tinggi $(T)=20 \mathrm{~cm}$. Adapun kontruksi perangkap (traps) lipat dapat dilihat pada Gambar 2.

\section{Pengoperasian Perangkap Lipat}

Pengoperasian alat tangkap perangkap lipat diuji cobakan selama 10 hari dengan menggunakan 24 perangkap lipat yang sebelumnya telah dibuat. Tahapan pengoperasian perangkap (traps) lipat adalah 1) tahap persiapan; 2) penentuan daerah penangkapan (fishing ground); 3) penurunan perangkap lipat (setting); 4) Perendaman perangkap lipat (soaking) dan 5) Pengangkatan perangkap lipat (hauling).

Hasil tangkapan perangkap lipat adalah kepiting bakau yang terklasifikasi dalam dua spesies yaitu spesies Scylla serrata dan Scylla tranquebarica. Untuk jenis hasil tangkapan kepiting bakau dapat dilihat pada Gambar 3 dan Gambar 4.

\section{PENUTUP}

\section{Kesimpulan}

Hasil kegiatan menunjukkan bahwa:

1) Adanya peningkatan hasil tangkapan kepiting bakau dengan menggunakan perangkap lipat dibandingkan dengan menggunakan alat tangkap serok;

2) Telah terjadi peningkatan keterampilan bagi masyarakat nelayan dalam pembuatan bubu lipat dan

3) Telah terjadi peningkatan pemahaman bagi masyarakat nelayan dalam penggunaan alat tangkap ramah lingkungan untuk penangkapan kepiting bakau

\section{UCAPAN TERIMA KASIH}

Ucapan terima kasih disampaikan kepada:

1) Kementerian Riset, Teknologi dan Pendidikan Tinggi yang telah memberikan pendanaan melalui hibah pengabdian kepada masyarakat skim Ipteks bagi Masyakat (IbM).

2) Nelayan perintis bubu lipat di Gampong Kuala Bubon Kecamatan Samatiga Kabupaten Aceh Barat sebagai pihak mitra.

3) Aparatur Gampong Gampong Kuala Bubon Kecamatan Samatiga yang telah memberikan ijin dan memfasilitasi kegiatan ini.

4) Bapak Mahendra, S.Pi., M.Si (Dosen Prodi Akuakultur Fakultas Perikanan dan Ilmu Kelautan Universitas Teuku Umar) dan Sdr. Ikhsan Saputra (tenaga lapang kegiatan $\mathrm{lbM}$ ) yang telah banyak membantu kegiatan ini.

\section{DAFTAR PUSTAKA}

Badan Pusat Statistik. 2016. Aceh Barat Dalam Angka 2016. Badan Pusat Statistik Kabupaten Aceh Barat, Meulaboh. 
DKP Provinsi Aceh. 2014. Statistik Perikanan Tangkap. Sumber dkp.acehprov.go.id diakses 10 Oktober 2017.

Charles, A.T. 2000. Sustainable fishery systems 2nd ed.1, ed., Malden, MA: Blackwell Science. 


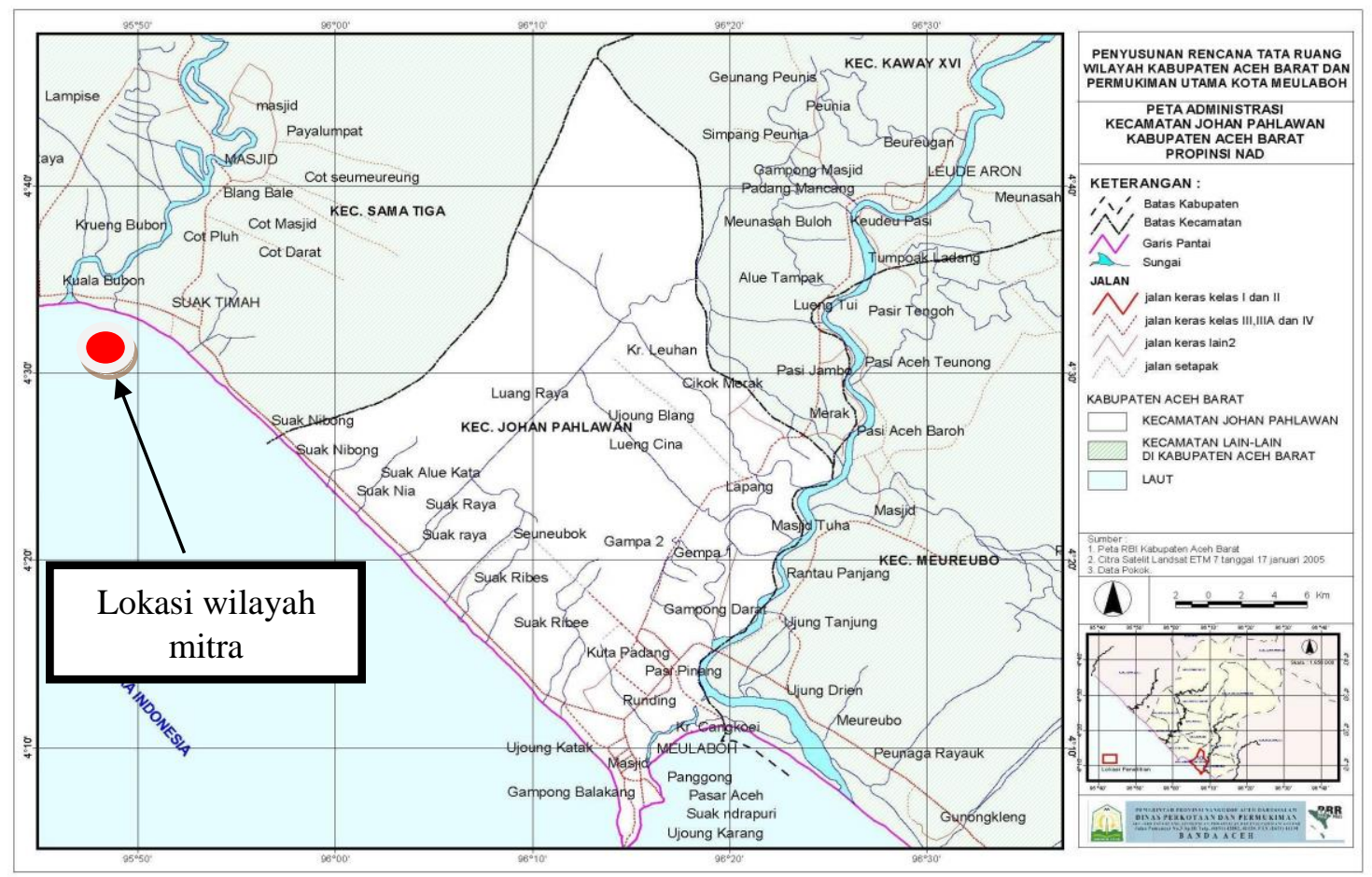

Gambar 1. Peta lokasi mitra nelayan perintis kepiting bakau

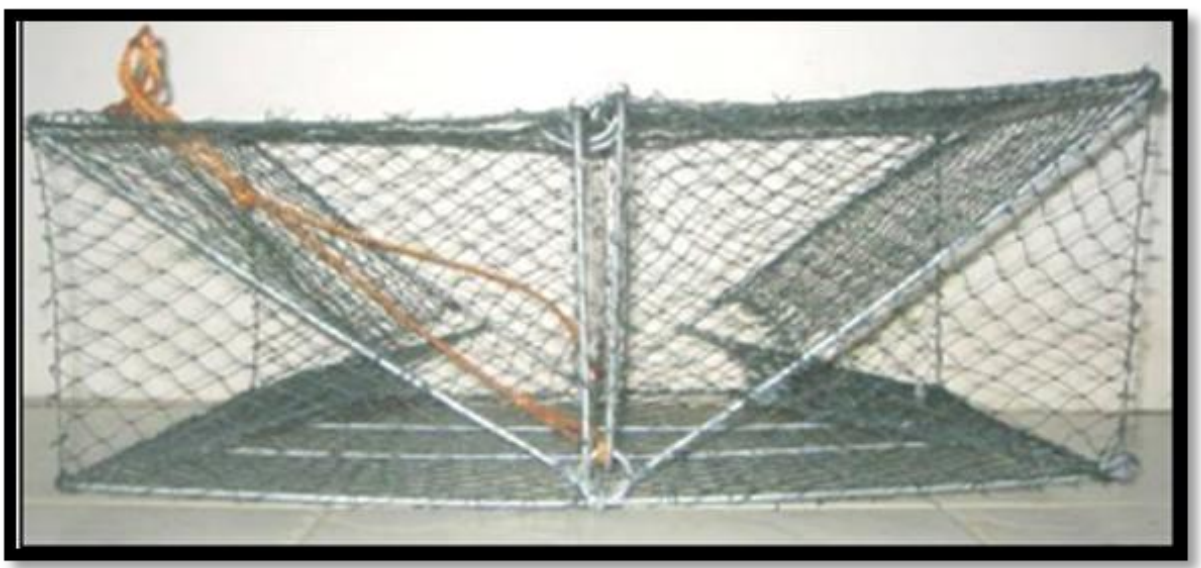

Gambar 2. Kontruksi perangkap (traps) lipat.

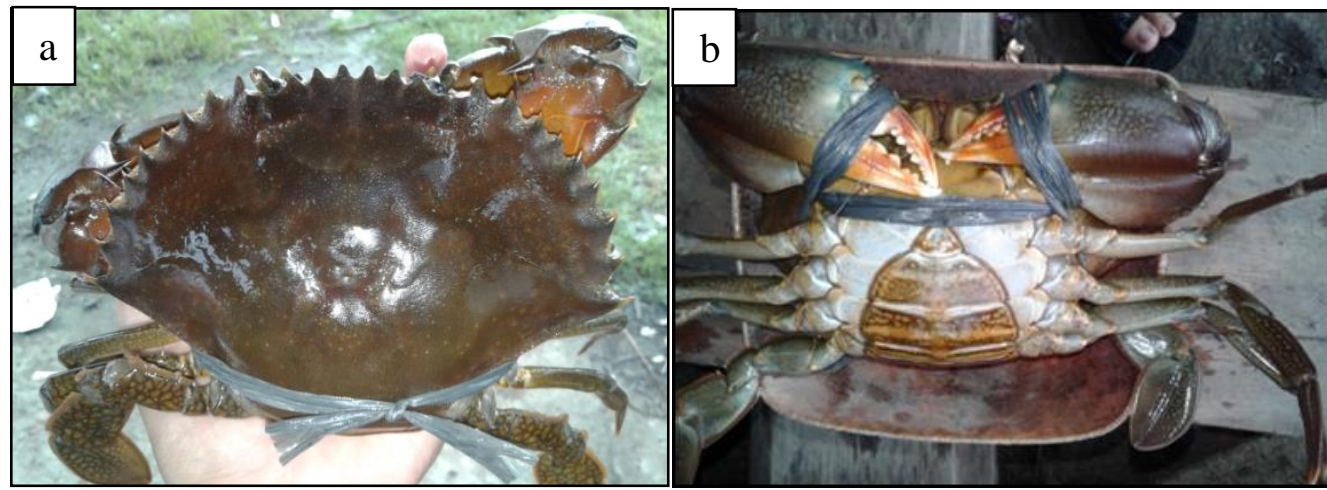

Gambar 3. Sisi kerapas (a) dan abdomen (b) dari Scylla serrata 


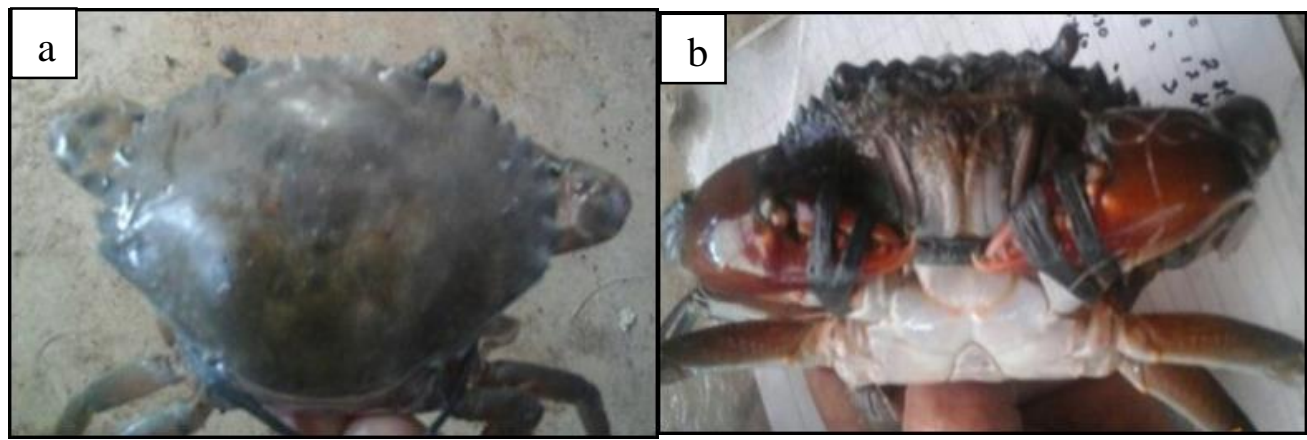

Gambar 4. Sisi kerapas (a) dan abdomen (b) dari Scylla tranquebarica

Tabel 1. Bahan perangkap lipat

\begin{tabular}{|c|c|c|}
\hline No & Jenis Bahan & Ukuran \\
\hline 1 & Kawat galvanis & $\Theta: 4 \mathrm{~mm}$ \\
\hline 2 & Jaring PE D9 & $\begin{array}{c}\Theta: 1,5 \\
\text { inch }\end{array}$ \\
\hline 3 & Jaring PE D9 & $\Theta: 1$ inch \\
\hline 4 & Benang PE D9 & - \\
\hline 5 & Tali tambang & $\Theta: 0,6 \mathrm{~cm}$ \\
\hline 6 & Tali tambang & $\Theta: 0,4 \mathrm{~cm}$ \\
\hline 7 & Pelampung tanda & $\begin{array}{c}\Theta: 2 \mathrm{~cm} \\
\mathrm{t}=3 \mathrm{~cm}\end{array}$ \\
\hline
\end{tabular}

